ISSN 1392-3196 / e-ISSN 2335-8947

Zemdirbyste-Agriculture, vol. 107, No. 3 (2020), p. 263-270

DOI 10.13080/z-a.2020.107.034

\title{
Biocontrol agent for apple Fusarium rot: optimization of production by Streptomyces hygroscopicus
}

\author{
Jovana GRAHOVAC ${ }^{1}$, Ivana MITROVIĆ ${ }^{1}$, Jelena DODIĆ ${ }^{1}$, Mila GRAHOVAC ${ }^{2}$, \\ Zorana RONČEVIĆ ${ }^{1}$, Siniša DODIĆ ${ }^{1}$, Aleksandar JOKIĆ ${ }^{1}$ \\ ${ }^{1}$ University of Novi Sad, Faculty of Technology \\ Bulevar Cara Lazara 1, Novi Sad 21000, Serbia \\ E-mail: tadi@uns.ac.rs \\ ${ }^{2}$ University of Novi Sad, Faculty of Agriculture \\ Trg Dositeja Obradovića 8, Novi Sad 21000, Serbia
}

\begin{abstract}
Postharvest Fusarium rot of apple fruit, caused by a fungal pathogen Fusarium avenaceum, has become a problem in apple storage in Serbia. Considering that chemical protection has a negative effect on human health and the environment, this research was done to find potential eco-ways of controlling Fusarium infection of apple fruit. The aim of this study was to examine the potential of Streptomyces hygroscopicus for control of two F. avenaceum isolates obtained from apple fruit exhibiting rot symptoms. As a first step, optimization of three the most important medium nutrients: glycerol $\left(\mathrm{C}_{3} \mathrm{H}_{8} \mathrm{O}_{3}\right)$, ammonium sulphate $\left.\left(\mathrm{NH}_{4}\right)_{2} \mathrm{SO}_{4}\right)$ and dipotassium phosphate $\left(\mathrm{K}_{2} \mathrm{HPO}_{4}\right)$, was performed in order to obtain their optimal concentrations. At the optimal medium composition, nine bioprocesses were performed in a laboratory bioreactor with a working volume of $2 \mathrm{dm}^{3}$ at different agitation speeds and aeration rates in order to determine, at which process conditions the highest production of the target antagonist occurs. Results of medium optimization showed that the optimal concentration of glycerol, ammonium sulphate and dipotassium phosphate are 19.59, 0.25 and $1.35 \mathrm{~g} \mathrm{dm}^{-3}$, respectively. Investigating the effect of agitation and aeration on the antagonistic agent production in nine bioprocessing conditions showed that antifungal activity of S. hygroscopicus supernatant obtained in the bioprocess with an agitation speed of $100 \mathrm{rpm}$ and aeration rate of 1.5 vvm is statistically significantly higher compared to that in other bioprocesses. Under these conditions, the highest production of antagonist agents was achieved after 96 hours of cultivation, forming the inhibition zone diameters of $F$. avenaceum KA12 and KA13 isolates of 59.33 and $55.67 \mathrm{~mm}$, respectively. The activity was also confirmed in planta.
\end{abstract}

Key words: bioprocess, eco-friendly control, Fusarium avenaceum, postharvest apple disease, soilborne streptomycetes.

\section{Introduction}

Thanks to its long-storage capability, apples are the subject of worldwide trade throughout the year, and quality storage conditions enable them to be sold on the market at a time when they reach their highest price. The apple market is very demanding so, after successful production in the field, growers have to pay special attention to their storage.

The following phytopathogenic fungi are listed as the most important causative agents of apple fruit rot in storage: Penicillium italicum, Penicillium expansum, Monilinia sp., Alternaria alternata, Botrytis cinerea, Colletotrichum gloeosporioide, Colletotrichum acutatum, while recently the presence of Fusarium avenaceum and other species from the genus Fusarium has also been mentioned (Sever et al., 2012; JuhnevicaRadenkova et al., 2016; Wenneker et al., 2016). In addition to the losses they cause, fungi from the genera Penicillium, Alternaria and Fusarium are potential

producers of mycotoxins harmful for human health, and their suppression is of great importance (Bjelić et al., 2018; Gashgari et al., 2019).

The use of chemical agents is common in plant protection. However, the intensive use of chemical agents in modern agriculture, including those used to control phytopathogenic fungi, has led to several problems related to environmental pollution and the emergence of resistant strains (Valiuškaitè et al., 2017). Because of all the above, in the last few years in focus is the search for alternative methods that can reduce the use of toxic agrochemicals (Singh, Chhatpar, 2011). Only two bio-products based on Bacillus subtilis have been registered in Serbia, but neither is intended for the treatment of apple fruit after harvest. Therefore, there are no registered products based on streptomycetes in Serbia, while in the world there are a few commercially available streptomycetes-based biofungicides (Jicheng et al., 2008;

Please use the following format when citing the article:

Grahovac J., Mitrović I., Dodić J., Grahovac M., Rončević Z., Dodić S., Jokić A. 2020. Biocontrol agent for apple Fusarium rot: optimization of production by Streptomyces hygroscopicus. Zemdirbyste-Agriculture, 107 (3): $263-270$. DOI $10.13080 / \mathrm{z}-\mathrm{a} .2020 .107 .034$ 
Cuppels et al., 2013).

Successful bioprocess and achievement of high yield of target components is ensured by optimized medium composition, ensuring growth of pure microorganism culture without contamination, maintaining the required temperature and acidity $(\mathrm{pH})$ during cultivation, preventing intensive foaming of the medium and supplying the culture with sufficient quantities of oxygen (Yi et al., 2015). In addition to medium composition, agitation and aeration play a key role in submerged cultivations (Mitrović et al., 2017). Agitation is an operation that ensures uniformity of conditions within the bioreactor. It involves the distribution of all bioprocess components, inoculum and nutrients as well as heat and dissolved oxygen. Also, streptomycetes are aerobic microorganisms and require oxygen for growth, reproduction and production of the metabolites. Streptomycetes vary in the demand for dissolved oxygen. While some species grow in low oxygen environments, others require its high level in the medium (Liang et al., 2008). Some scientists have confirmed the potential of streptomycetes in the control of phytopathogenic fungi (Shimizu et al., 2009; Shakeela et al., 2016), but researches about control of Fusarium as a potential causative agent of apple disease by streptomycetes are very rare.

As a result, the aim of this study was to optimize the medium composition and selected process parameters in order to obtain a storage apple pathogen antagonist effective against two $F$. avenaceum isolates using Streptomyces hygroscopicus.

\section{Materials and methods}

Pathogenic fungi. Fusarium isolates (Fusarium avenaceum KA12 and $F$. avenaceum KA13), were obtained in 2012 from apple fruit samples showing rot symptoms. Apple fruits were harvested at optimal time. Fruit maturity was determined by a starch-iodine test, and apple fruits were stored in an ultra-low oxygen (ULO) storage under the following conditions: $92 \pm 1 \%$ relative humidity, $1 \pm 0.3^{\circ} \mathrm{C}$ temperature, $0.8 \% \mathrm{O}_{2}$ (oxygen) and $1 \% \mathrm{CO}_{2}$ (carbon dioxide), in Vojvodina Province, Serbia. Apple samples were collected after four months of storage, due to reported early occurrence of rot symptoms in the ULO storage. After isolation, identification and pathogenicity confirmation, the obtained isolates were kept on potato dextrose agar (PDA) slants and revitalised every six months. The occurrence of these two phytopathogenic species is increasing annually in the apple storage in Serbia. Trials on antagonistic activity were conducted in 2017 and 2018.

Isolation of the pathogens was conducted as follows: infected apples were surface-sterilized with $96 \%$ ethanol, cut at the turn of diseased to healthy tissue, and tissue fragments were aseptically placed on a sterile PDA medium and incubated at $25^{\circ} \mathrm{C}$ temperature for seven days (Dhingra, Sinclair, 2019). After seven days, 15 isolates were selected and the obtained mycelium was subcultured to a sterile PDA medium to obtain a pure culture. Further, 8 monosporic isolates of Fusarium spp. were selected, incubated for three days on PDA slants at $20^{\circ} \mathrm{C}$ temperature and kept in a refrigerator at $4^{\circ} \mathrm{C}$ temperature until use with regular revitalization every six months. Pathogenicity of isolates was tested on artificially inoculated injured apples, and pathogenicity of re-isolates was confirmed in the same way. Noninfected fruits (control) did not show any symptoms of the disease. After proven pathogenicity, two isolates of Fusarium spp. were selected and molecularly identified.

The isolates were identified according to pathogenic, morphological, ecological and molecular characteristics. For molecular identification purposes, genomic DNA was extracted from pure cultures using DNeasy Plant Mini Kit (Qiagen Inc., USA) and manufacturer's recommendations. Molecular identification of Fusarium isolates was conducted by polymerase chain reaction (PCR), using universal primers ITS1 (TCCGTAGGTGAACCTGCGG) and ITS4 (TCCTCCGCTTATTGATATGC) (Wasinpiyamongkol, Kanchanaphum, 2019). Amplification reactions were carried out in $25 \mu \mathrm{L}$ reaction mixture containing $2 \times$ Master mix (Fermentas, Lithuania): $0.625 \mathrm{U}$ of Taq DNA polymerase, $2 \mathrm{mM} \mathrm{MgCl}_{2}$ (magnesium chloride), 0.2 $\mathrm{mM}$ each of dNTPa (deoxyribonucleotide triphosphate), $1 \mu \mathrm{l}$ of isolated DNA and $1 \mu \mathrm{L}$ of each primer $(0.2 \mathrm{mM})$.

Reaction of the PCR mix without added DNA served as a negative control. PCR reactions were performed in Eppendorf Master Cycler (Eppendorf, Germany). The program consisted of an initial denaturing step at $94^{\circ} \mathrm{C}$ for $1.5 \mathrm{~min}$, followed by 29 cycles of 30 sec at $94^{\circ} \mathrm{C}, 30 \mathrm{sec}$ at $55^{\circ} \mathrm{C}$ and $30 \mathrm{sec}$ at $72^{\circ} \mathrm{C}$ and final extension step at $72^{\circ} \mathrm{C}$ for $9.5 \mathrm{~min}$. PCR products were separated by horizontal gel electrophoresis in $1 \%(\mathrm{w} / \mathrm{v})$ agarose gel in $1 \times$ TBE (Tris-Borate-EDTA). Gels were stained in ethidium bromide solution and visualized under UV light. PCR products were purified using miPCR Purification Kit (Metabion International, Germany), alignment and edition were carried out with the sequence alignment editor BioEdit 7.0 (Isis Pharmaceuticals Inc., USA) and visually corrected. Then sequences were compared with those available in the GenBank database.

For antagonistic activity trials, the isolates were initially grown on PDA plates for seven days, and a small amount of mycelium of each isolate was added to flasks containing $50 \mathrm{~mL}$ PDA. The flasks were incubated for $48 \mathrm{~h}$ on a rotary shaker $(150 \mathrm{rpm})$ at $25^{\circ} \mathrm{C}$ temperature. Before use, culture liquid was filtered through double layer of sterile cheesecloth.

Antagonist and inoculum preparation. In the presented study as antagonist was used Streptomyces hygroscopicus (GenBank accession No. KT026467), provided by Microbial Culture Collection of Faculty of Technology, University of Novi Sad, Serbia. The bacteria were kept frozen in growth medium containing $20 \%(\mathrm{w} / \mathrm{v})$ glycerol $\left(\mathrm{C}_{3} \mathrm{H}_{8} \mathrm{O}_{3}\right)$ solution and propagated twice at $27^{\circ} \mathrm{C}$ temperature before use. Growth medium $(\mathrm{pH} 7 \pm 0.1)$ with a composition $\left(\mathrm{g} \mathrm{dm}^{-3}\right)$ : glucose $(15.0)$, soybean meal (10.0), $\mathrm{CaCO}_{3}(3.0), \mathrm{NaCl}(3.0), \mathrm{MgSO}_{4}(0.5)$, ammonium sulphate $\left(\mathrm{NH}_{4}\right)_{2} \mathrm{SO}_{4}(0.5)$ and dipotassium phosphate $\left(\mathrm{K}_{2} \mathrm{HPO}_{4}\right)(1.0)$, was used for inoculum preparation.

Modelling and optimization of medium composition. In accordance with the results previously obtained, data from scientific literature (Chen et al., 2011) and based on applied experimental plan, the content of carbon $\left(\mathrm{C}_{3} \mathrm{H}_{8} \mathrm{O}_{3}\right)$, nitrogen $\left(\left(\mathrm{NH}_{4}\right)_{2} \mathrm{SO}_{4}\right)$ and phosphorus $\left(\mathrm{K}_{2} \mathrm{HPO}_{4}\right)^{3}$ varied in the medium for cultivation of $S$. hygroscopicus. In addition to the selected variables (Table1), the following nutrients were also used to formulate the medium for biosynthesis $\left(\mathrm{g} \mathrm{dm}^{-3}\right): \mathrm{CaCO}_{3}$ (3.0), $\mathrm{NaCl}(3.0)$ and $\mathrm{MgSO}_{4}(0.5)$. The $\mathrm{pH}$ of the medium was adjusted to $7.0 \pm 0.1$ prior to sterilization using 1 $\mathrm{M} \mathrm{HCl}$ (hydrochloric acid) and $1 \mathrm{M} \mathrm{NaOH}$ (sodium hydroxide).

Inoculation of the cultivation medium was performed by adding $10 \%(\mathrm{v} / \mathrm{v})$ of inoculum prepared on growth medium with external mixing with a laboratory shaker, $150 \mathrm{rpm}$ at $26 \pm 1^{\circ} \mathrm{C}$ temperature for $72 \mathrm{~h}$. This experimental design has three centre points and a total of 15 observations (Table 1). Erlenmeyer flasks $300 \mathrm{~mL}$ with $100 \mathrm{~mL}$ of culture medium were inoculated and incubated for 7 days at $26 \pm 1{ }^{\circ} \mathrm{C}$ temperature under aerobic conditions. For mixing and external aeration of the cultivation liquid, a rotary shaker (IKA KS 4000i Control Incubating Shaker) at $150 \mathrm{rpm}$ was used. 
Table 1. Combinations of three experimental factors and values of modelled responses of two Fusarium avenaceum isolates

\begin{tabular}{|c|c|c|c|c|}
\hline \multicolumn{3}{|c|}{ Experimental factors (medium nutrients) } & \multicolumn{2}{|c|}{ Measured response (isolates) } \\
\hline $\mathrm{C}_{3} \mathrm{H}_{8} \mathrm{O}_{3}$ & $\left(\mathrm{NH}_{4}\right)_{2} \mathrm{SO}_{4}$ & $\mathrm{~K}_{2} \mathrm{HPO}_{4}$ & KA12 & KA13 \\
\hline & $\mathrm{g} \mathrm{dm}^{-3}$ & & \multicolumn{2}{|c|}{ inhibition zone diameter $\mathrm{mm}$} \\
\hline 5 & 0.25 & 2 & 21 & 23 \\
\hline 20 & 0.25 & 2 & 25 & 26 \\
\hline 5 & 0.75 & 2 & 23 & 25 \\
\hline 20 & 0.75 & 2 & 19 & 18 \\
\hline 5 & 0.5 & 1 & 17 & 21 \\
\hline 20 & 0.5 & 1 & 22 & 22 \\
\hline 5 & 0.5 & 3 & 22 & 22 \\
\hline 20 & 0.5 & 3 & 17 & 17 \\
\hline 12.5 & 0.25 & 1 & 17 & 19 \\
\hline 12.5 & 0.75 & 1 & 17 & 17 \\
\hline 12.5 & 0.25 & 3 & 17 & 17 \\
\hline 12.5 & 0.75 & 3 & 17 & 17 \\
\hline 12.5 & 0.5 & 2 & 17 & 17 \\
\hline 12.5 & 0.5 & 2 & 17 & 17 \\
\hline 12.5 & 0.5 & 2 & 17 & 17 \\
\hline
\end{tabular}

Fermentation runs. Nine experiments were carried out in a $3 \mathrm{dm}^{3}$ laboratory-scale bioreactor Biostat Aplus (Sartorius AG, Germany) with $2 \mathrm{dm}^{3}$ working volume and automatic measurement and control of all process parameters. A $10 \%$ of fresh culture described earlier was inoculated in the bioreactor, containing optimized media $\left(\mathrm{g} \mathrm{dm}^{-3}\right): \mathrm{C}_{3} \mathrm{H}_{8} \mathrm{O}_{3}(19.59),\left(\mathrm{NH}_{4}\right)_{2} \mathrm{SO}_{4}$ (0.25), K $\mathrm{HPO}^{(1.35),} \mathrm{CaCO}_{3}{ }^{3}(3.0), \mathrm{NaCl}^{4}(3.0)$ and $\mathrm{MgSO}_{4}(0.5)$ at $\mathrm{pH} 7.0 \pm 0.1$. Experiments were conducted at agitation speeds of 100, 200 and $300 \mathrm{rpm}$. The corresponding aeration rate was adjusted to $0.5,1.0$ and $1.5 \mathrm{vvm}, 1 \mathrm{~L}$ of air passing through $1 \mathrm{~L}$ of medium in $1 \mathrm{~min}$, respectively. Aeration was accomplished by using sterile air aeration system. Agitation was provided with a pair of Rushton impellers without internal baffles, while aeration was conducted with sterile air using an aeration system. Temperature was controlled at $26 \pm 1^{\circ} \mathrm{C}$. The samples were collected every $12 \mathrm{~h}$ of cultivation and centrifuged at $10000 \mathrm{rpm}$ for $15 \mathrm{~min}$ at $20^{\circ} \mathrm{C}$ temperature with an Eppendorf centrifuge 5804 (Germany). In the further work, only liquid phase of cultivation medium was used.

Experimental design and data processing. All experiments were carried out in triplicate and the results were averaged. The experiments were carried out in accordance with the Box-Behnken design with three factors on three levels and three repetitions in the center point (Ferreira et al., 2007).

Table 1 shows the three variables used for fitting the following second-order mathematical model:

$$
Y=b_{0}+\sum_{b_{i} X_{i}}+\sum_{b_{i i}{ }^{2} X_{i i}{ }^{2}}+\sum_{b_{i j} X_{i} X_{j}}
$$

where $\mathrm{Y}$ is the measured response (inhibition zone diameter against $F$. avenaceum KA12 and KA13 isolates), $b_{0}$ - the intercept, $b_{i}$ - the linear, $b_{i i}$ - quadratic, $b_{i j}$ - interaction effect of the factors.

In vitro antifungal activity. Petri plates $85 \mathrm{~mm}$ diameter were used for in vitro testing by wells technique (Grahovac et al., 2014). According to this technique, two layers of PDA medium were applied in plates. The first layer consisted of $2 \%$ PDA medium; the second layer was composed of $1.2 \%$ PDA and filtered fungal culture liquid $(35 \%)$ was added. Three wells with a diameter of $15 \mathrm{~mm}$ represented one treatment and $100 \mu \mathrm{l}$ of test liquid was added in each well. In control plates, $100 \mu$ l of sterile distilled water was added to wells. In vitro antagonistic activity of the $S$. hygroscopicus supernatant against two Fusarium isolates grown on PDA was determined every $12 \mathrm{~h}$ of cultivation in the bioreactor and after 7 days of cultivation in Erlenmeyer flasks.

The assessment of antagonistic activity was done after $72 \mathrm{~h}$ incubation at $27^{\circ} \mathrm{C}$ temperature by measuring diameter of inhibition zones $(\mathrm{mm})$ - zones around wells with no visible mycelia growth of two Fusarium isolates.

In planta antagonistic activity was performed to confirm antifungal activity on mature apple ('Golden Delicious') fruits of a similar size. Each fruit was surface sterilized by dipping in $70 \%$ ethanol for $2 \mathrm{~min}$ and washed with sterile distilled water. The fruits were wounded with a sterile nail $(4 \mathrm{~mm}$ diameter and $3 \mathrm{~mm}$ depth). A $10 \mathrm{~mL}$ drop of centrifuged cultivation liquid of $S$. hygroscopicus was added to each wound prior to inoculation, which was performed by adding a mycelia plug ( $3 \mathrm{~mm}$ diameter) of the tested fungal $F$. avenaceum isolates KA12 and KA13 into each wound. As a control treatment, sterile distilled water was used. Surfacesterilized, wounded, uninoculated apple fruits served as a confirmation of successful surface-sterilization process resulting in no biological surface-contamination as well as in absence of negative effects of sterilization on the fruits. Each treatment was tested in triplicate and one fruit with two wounds represented one replicate. The fruits were placed on two layers of moist paper towels on a wire rack in a plastic container at $21-23^{\circ} \mathrm{C}$ temperature and $97 \%$ relative humidity. The diameter of developed necrotic lesions on the inoculated fruits was measured 10 days after inoculation.

Statistical analysis of the experimental results was performed using software Statistica, version 13.0 (StatSoft Inc., USA). Response surface plots were generated with the same software and drawn for a constant value of one of the factors (nutrient), while the remaining two factors (medium nutrients) were varied. For determination of optimal values of examined factors, the method of desired function was applied using software Design-Expert, version 7.01 (State-Ease Inc., USA). Results of testing the most suitable cultivation conditions for the purpose of production of the largest amount of antagonist agent were processed by one-way analysis of variation (ANOVA) \pm standard deviation (SD) using software Statistica. Duncan's multiple range test was used to test significance of differences $(p \leq 0.05)$ between mean values of measured inhibition zone diameter.

\section{Results and discussion}

Fungal pathogen isolation and identification. Based on $100 \%$ ITS nucleotide sequence identities to the Fusarium genus in the GenBank and morphological features, both isolates, marked as KA12 and KA13, were identified as $F$. avenaceum.

Mathematical models for inhibition zone diameter on Fusarium avenaceum isolates. The influence of carbon $(\mathrm{C})$, nitrogen $(\mathrm{N})$ and phosphorus 
(P) sources on the yield of active components effective against storage pathogens of $F$. avenaceum species were investigated by measuring the inhibition zone diameter of the mycelia growth. The obtained results were fitted with a second-order polynomial to define mathematical models, which describe the influence of varied factors on the observed response (Table 1).

The regression coefficients, their significance (marked bold) and the coefficients of determination are shown in Table 2. Since the obtained coefficients of determination for the two test isolates are greater than 0.900 , it can be concluded that the experimental results are very well fitted with the second order polynomial (Hong et al., 2009).
The results shown in Table 2 concerning the regression equation for the inhibition zone diameter of the $F$. avenaceum KA12 isolate show that a large number of equation members significantly affect the production of antagonistic agent effective against the tested phytopathogenic fungi. Observing linear members, only the coefficient of initial $\mathrm{N}$ content had no statistically significant effect on the observed response, whereas for square members, the contents of all three nutrients in the Streptomyces hygroscopicus medium showed statistical significance. For members describing the significance of the interactions of individual nutrients on the observed response, the interactions of glycerol with the $\mathrm{N}$ source and glycerol with the dipotassium phosphate source

Table 2. Regression equation coefficients for selected responses

\begin{tabular}{|c|c|c|c|c|}
\hline \multirow{2}{*}{$\frac{\text { Response }}{\text { Effects }}$} & \multicolumn{2}{|c|}{$\begin{array}{c}\mathrm{Y}_{1}-\text { inhibition zone diameter } \\
\text { F. avenaceum KA12 }\end{array}$} & \multicolumn{2}{|c|}{$\begin{array}{c}\mathrm{Y}_{2}-\text { inhibition zone diameter } \\
\text { F. avenaceum KA13 }\end{array}$} \\
\hline & coefficient & $p$-value & coefficient & $p$-value \\
\hline \multicolumn{5}{|c|}{ Intercept } \\
\hline$b_{0}$ & 25.3333 & 0.000489 & 13.41679 & 0.004967 \\
\hline \multicolumn{5}{|c|}{ Linear } \\
\hline$b_{1}$ & -1.0667 & 0.004129 & -0.46667 & 0.058523 \\
\hline$b_{2}^{1}$ & -15.3333 & 0.08055 & -8.66672 & 0.22426 \\
\hline$b_{3}^{2}$ & 4.7500 & 0.042370 & 9.16665 & 0.002043 \\
\hline \multicolumn{5}{|c|}{ Quadratic } \\
\hline$b_{11}$ & 0.0800 & 0.000065 & 0.06667 & 0.000091 \\
\hline$b_{22}^{11}$ & 24.0000 & 0.009576 & 19.99981 & 0.012660 \\
\hline$b_{33}^{2 L}$ & -1.00000 & 0.041901 & -1.2500 & 0.012659 \\
\hline \multicolumn{5}{|c|}{ Interaction } \\
\hline$b_{12}$ & -1.3333 & 0.000875 & -1.06666 & $\mathbf{0 . 0 0 1 4 5 7}$ \\
\hline$b_{13}^{12}$ & -0.2000 & 0.008149 & -0.3333 & 0.000521 \\
\hline$b_{23}$ & 2.0000 & 0.216437 & 0.00003 & 0.999985 \\
\hline$R^{2}$ & \multicolumn{2}{|c|}{0.982} & \multicolumn{2}{|c|}{0.981} \\
\hline
\end{tabular}

were statistically significant. In both interactions, a negative sign indicates an antagonistic effect. Influence of these interactions on the inhibition zone diameter of $F$. avenaceum KA12 isolate is shown in Figure 1.
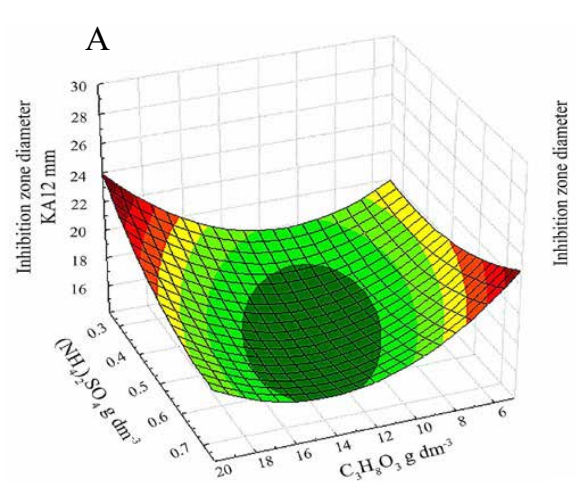

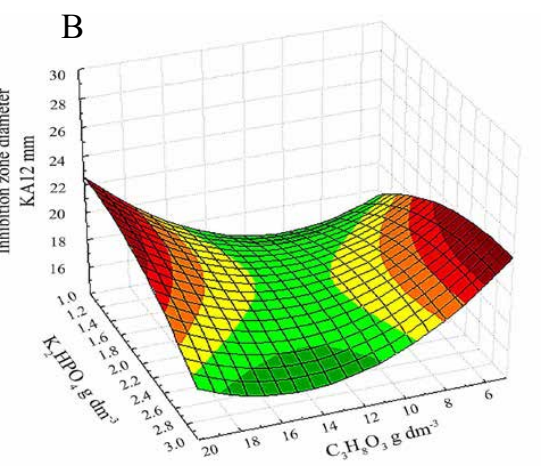

B
Figure 1A shows the predicted effect of glycerol and ammonium sulphate content on the inhibition of $F$. avenaceum KA12 isolate when constant value of dipotassium phosphate content in the medium $\left(2 \mathrm{~g} \mathrm{dm}^{-3}\right)$

Figure 1. Impact of two factors (shown on $\mathrm{x}$ and $\mathrm{y}$ axis) interaction on the inhibition of Fusarium avenaceum KA12 isolate growth at constant value of the third factor: dipotassium phosphate $\left(\mathrm{K}_{2} \mathrm{HPO}_{4}\right)(\mathrm{A})$, ammonium sulphate $\left(\mathrm{NH}_{4}\right)_{2} \mathrm{SO}_{4}(\mathrm{~B})$ and glycerol $\left(\mathrm{C}_{3} \mathrm{H}_{8} \mathrm{O}_{3}\right)(\mathrm{C})$

was applied. The results presented on the response surface plot show that the observed response value increased with glycerol content increasing in the medium and reached the maximum value when the glycerol content was highest $\left(20 \mathrm{~g} \mathrm{dm}^{-3}\right)$, if at the same time the ammonium sulphate content was the lowest $\left(0.25 \mathrm{~g} \mathrm{dm}^{-3}\right)$.

Like the previous influence, the effect of glycerol and dipotassium phosphate content interaction on the inhibition of $F$. avenaceum KA12 isolate with constant ammonium sulphate content was also a statistically significant member of the regression equation for the inhibition zone diameter of test isolate (Fig. 1B). Observing the response surface, it can be concluded that the inhibition zone diameter increased with increasing of glycerol content in the medium, if the content of dipotassium phosphate was $1 \mathrm{~g} \mathrm{dm}^{-3}$. However, the value

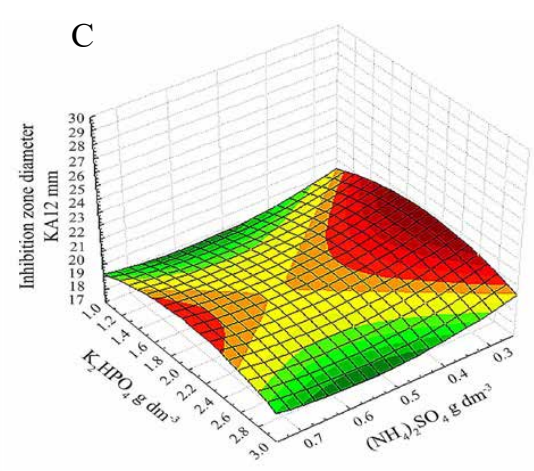

of the observed response shows the high value when the lowest concentration of glycerol $\left(5 \mathrm{~g} \mathrm{dm}^{-3}\right)$ and the highest concentration of dipotassium phosphate $\left(3 \mathrm{~g} \mathrm{dm}^{-}\right.$ ${ }^{3}$ ) were present in the medium. These results indicate that use of one of the nutrients in the smallest amount from the test range probably limit the biomass production, which caused an earlier stationary phase, in which the target antagonist agents were produced. Early stationary phase potentially means that the active metabolites will be synthesized earlier, which contributes to the shortening of the bioprocess and thus also affects the economics of the bioprocess.

Figure $1 \mathrm{C}$ represents the effect of ammonium sulphate and dipotassium phosphate content on F. avenaceum KA12 isolate inhibition when glycerol content was constant $\left(12.5 \mathrm{~g} \mathrm{dm}^{-3}\right)$ in the medium. The 
results show that the highest value of the observed response was achieved when in the substrate the amount of ammonium sulphate was the lowest of the test range $\left(0.25 \mathrm{~g} \mathrm{dm}^{-3}\right)$, and the content of dipotassium phosphate was between 1.8 and $2.6 \mathrm{~g} \mathrm{dm}^{-3}$.

The regression equation for the inhibition zones diameter of $F$. avenaceum KA13 isolate is shown in Table 2. Observing the linear members of the equation, the coefficients of dipotassium phosphate content are statistically significant, while all square members show statistical significance $(p<0.05)$. Observing a member of the equation describing the influence of the interaction of the two nutrients with the constant content of the third in the medium, the obtained results coincide with those obtained in the previously tested Fusarium isolate.

Figure 2 represents the impact of two factors interaction on the inhibition of $F$. avenaceum KA13 isolate at constant value of the third factor. The obtained response plots are very similar to those obtained for F. avenaceum KA12 isolate. Based on the coincidence of the results obtained for both tested isolates, it can be concluded that the produced antagonistic agent shows action on fungal isolates, which was expected since both isolates belong to the same species $F$. avenaceum.
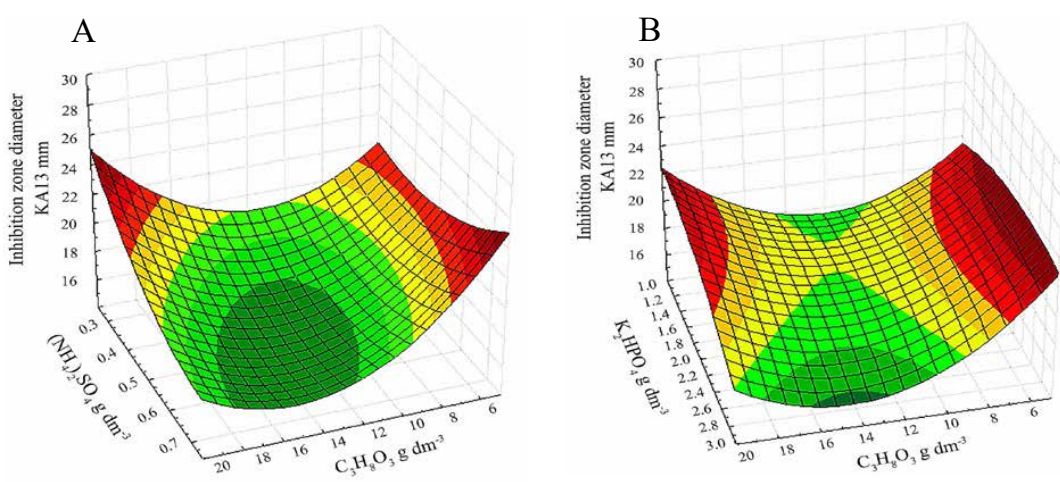

Optimization of medium composition. In order to maximize the productivity of microorganism producer, the medium composition should be optimized. Optimization processes can be applied to optimize processes with more than one response, but the concept of the desirability function is most often applied. Overall desirability function is geometric mean of the individual desirability functions and ranges from 0 to 1 (Rončević et al., 2019). In our study, the term desirability function was used to optimize the content of glycerol, ammonium sulphate and dipotassium phosphate in the medium for the production of storage apple pathogen antagonist effective against two $F$. avenaceum isolates using $S$. hygroscopicus.

The aim of the optimization was to define the medium composition that would provide the maximum production of storage apple pathogen antagonist against tested Fusarium isolates. Therefore, maximum inhibition zones diameters of the $F$. avenaceum KA12 and KA13 isolates were set as optimization targets, while the values of other variables were defined in the range.

The results show that the defined aims were achieved with an overall desirability function value of 1 at initial glycerol, ammonium sulphate and dipotassium phosphate values of $19.59,0.25$ and $1.35 \mathrm{~g} \mathrm{dm}^{-3}$,

Figure 2. Impact of two factors (shown on $\mathrm{x}$ and $\mathrm{y}$ axis) interaction on the inhibition of Fusarium avenaceum KA13 isolate growth at constant value of the third factor: dipotassium phosphate $\left(\mathrm{K}_{2} \mathrm{HPO}_{4}\right)(\mathrm{A})$, ammonium sulphate $\left(\mathrm{NH}_{4}\right)_{2} \mathrm{SO}_{4}(\mathrm{~B})$ and glycerol $\left(\mathrm{C}_{3} \mathrm{H}_{8} \mathrm{O}_{3}\right)(\mathrm{C})$

respectively. Since the overall desirability function has the maximum possible value (1), the obtained values of the tested medium nutrients represent the optimal solution for observed system (Fig. 3). Using the obtained values of the medium composition, the predicted values of the inhibition zone diameter for $F$. avenaceum KA12 and KA13 isolates were 26.6 and $25.4 \mathrm{~mm}$, respectively.

Therefore, a medium containing $19.59 \mathrm{~g} \mathrm{dm}^{-3}$ $\mathrm{C}_{3} \mathrm{H}_{8} \mathrm{O}_{3}, 0.25 \mathrm{~g} \mathrm{dm}^{-3}\left(\mathrm{NH}_{4}\right)_{2} \mathrm{SO}_{4}$ and $1.35 \mathrm{~g} \mathrm{dm}^{-3} \mathrm{~K}_{2} \mathrm{HPO}_{4}$ will be used in further studies. In addition to these three most important nutrients, the cultivation medium also contains the following components $\left(\mathrm{g} \mathrm{dm}^{-3}\right): \mathrm{CaCO}_{3}$ (3.0), $\mathrm{NaCl}$ (3.0) and $\mathrm{MgSO}_{4}(0.5)$.

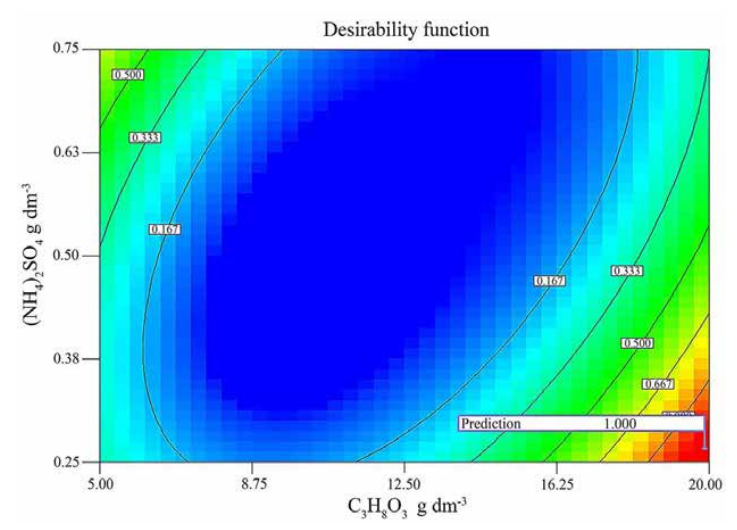

Figure 3. Medium optimization using desirability function concept
Effect of agitation and aeration rate on the antagonistic agent production. The effect of S. hygroscopicus supernatant obtained by sampling every $12 \mathrm{~h}$ in bioprocesses performed at different agitation speed and aeration rate in a laboratory bioreactor on test $F$. avenaceum phytopathogenic isolates was investigated below. Figures 4-6 present the results of the inhibition zones diameter obtained by the well technique.

Figure 4 shows antagonist agent production during 7 days of bioprocess in bioreactors with an agitation speed of $100 \mathrm{rpm}$ and aeration rate of $0.5,1$ and 1.5 vvm by $S$. hygroscopicus. It can be concluded that increasing the aeration rate from $0.5 \mathrm{vvm}$ to $1.5 \mathrm{vvm}$ at the same agitation speed of $100 \mathrm{rpm}$ resulted in a significant increase in antifungal activity of S. hygroscopicus supernatant. The largest production was achieved in the bioprocess with an agitation speed of $100 \mathrm{rpm}$ and aeration rate of $1.5 \mathrm{vvm}$ in $96 \mathrm{~h}$ of cultivation $S$. hygroscopicus supernatant. Under these conditions, a mean value of inhibition zone diameter of $F$. avenaceum KA12 and KA13 isolates amounted to 59.33 and $55.67 \mathrm{~mm}$, respectively. This is consistent with the results of Sousa et al. (2002), who have examined the production of actinomycin D using $S$. parvulus and also found that aeration increases from 0.5 to $1.5 \mathrm{vvm}$, leading to an increase in the active compound.

On the other hand, Yen and Li (2014) examined the effect of aeration on rapamycin production using $S$. hygroscopicus and found that aeration of $1.5 \mathrm{vvm}$ gave the best yield of this compound. Also, an increase in aeration rate leads to earlier production of antagonist 

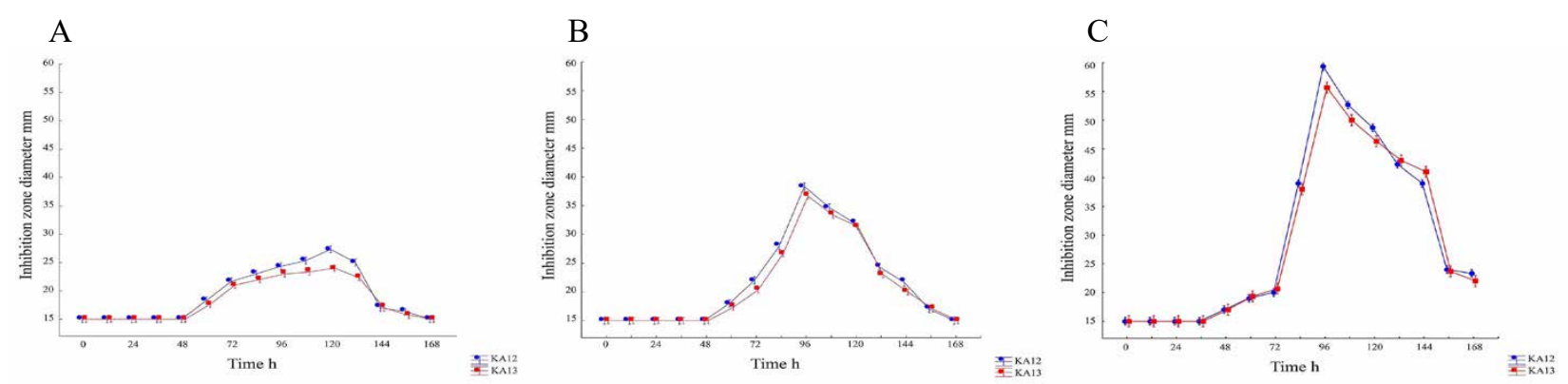

Figure 4. Mean values of inhibition zone diameter on Fusarium avenaceum KA12 and KA13 isolates obtained by the action of the Streptomyces hygroscopicus supernatant in a bioreactor with an agitation speed of $100 \mathrm{rpm}$ and aeration rate: $0.5 \mathrm{vvm}(\mathrm{A}), 1 \mathrm{vvm}(\mathrm{B})$ and $1.5 \mathrm{vvm}(\mathrm{C})$

agent. Thus, it can be concluded that the aeration rate is a very important process parameter, which is responsible for the oxygen transfer, growth and production of antagonistic agent in the laboratory bioreactor by S. hygroscopicus.

Figure 5 shows the mean value of inhibition zone diameter of the $S$. hygroscopicus supernatant on two test phytopathogen isolates during 7 days of cultivation in a bioreactor with an agitation speed of $200 \mathrm{rpm}$ and aeration rate of $0.5,1$ and $1.5 \mathrm{vvm}$. By comparing the results, it can be concluded that a stationary growth phase, at which maximum antifungal activity of S. hygroscopicus supernatant occurs, starts earlier with aeration increase (Yen, $\mathrm{Li}, 2014$ ). This fact confirms that the produced antagonist is a secondary metabolite, and since both isolates exhibit similar sensitivity, it can be concluded that the same component(s) is/are responsible for the antagonist activity. Streptomycetes are uncommon pathogens though infections in humans, such as mycetoma, can be caused by $S$. somaliensis and S. sudanensis (Hasani et al., 2014). Certainly, there is almost no information about pathogenicity of S. hygroscopicus for humans, indicating the possibility of its application as a biocontrol agent.

Figure 6 shows that the zones obtained in bioreactor with an agitation speed of $300 \mathrm{rpm}$ are significantly smaller than those obtained in bioreactors with agitation speeds of 100 and $200 \mathrm{rpm}$.
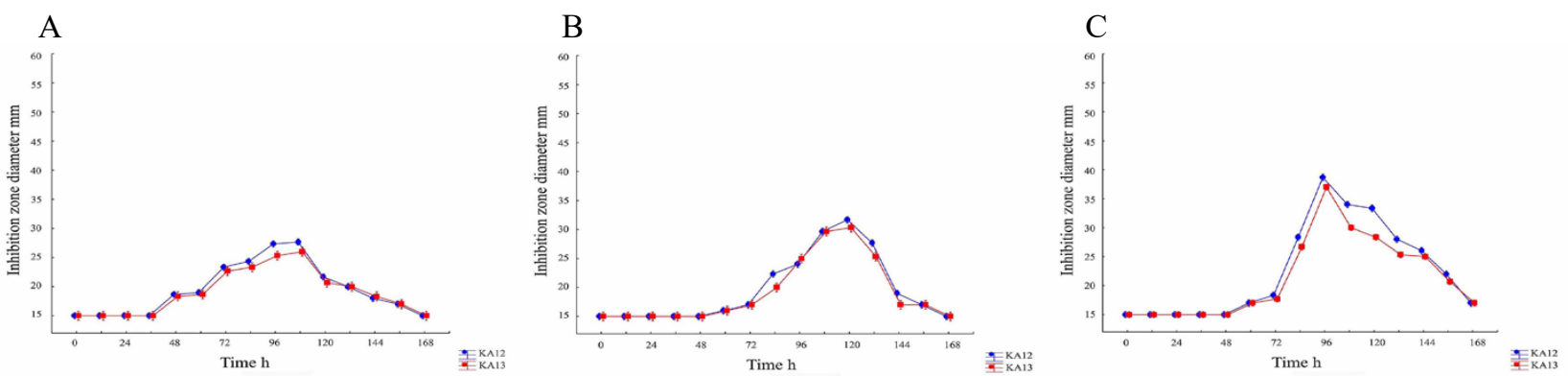

Figure 5. Mean values of inhibition zone diameter on Fusarium avenaceum KA12 and KA13 isolates obtained by the action of the Streptomyces hygroscopicus supernatant in a bioreactor with agitation speed of $200 \mathrm{rpm}$ and aeration rate: $0.5 \mathrm{vvm}(\mathrm{A}), 1 \mathrm{vvm}(\mathrm{B})$ and $1.5 \mathrm{vvm}(\mathrm{C})$
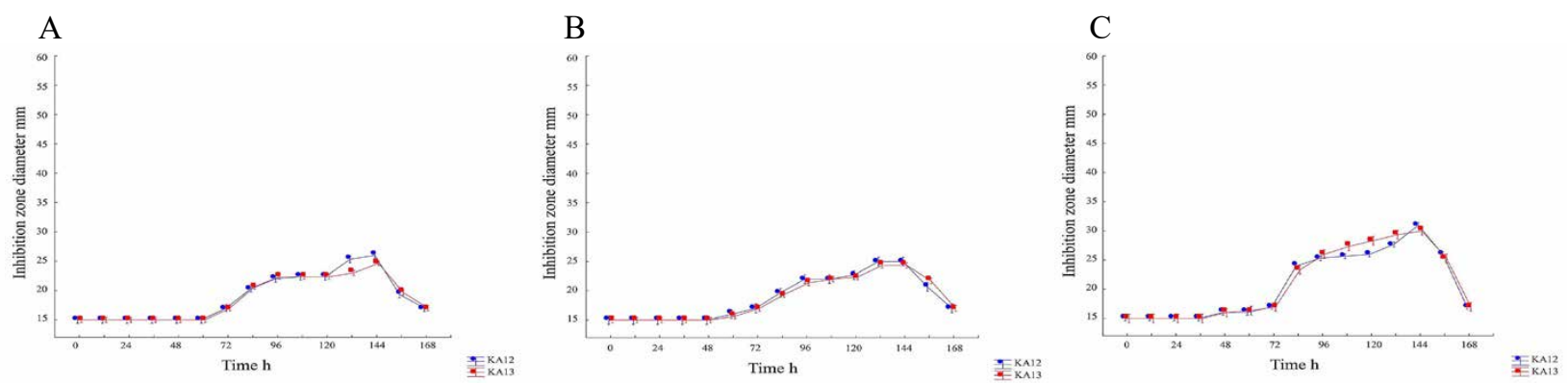

Figure 6. Mean values of inhibition zone diameter on Fusarium avenaceum KA12 and KA13 isolates obtained by the action of the Streptomyces hygroscopicus supernatant in a bioreactor with agitation speed of $300 \mathrm{rpm}$ and aeration rate: $0.5 \mathrm{vvm}(\mathrm{A}), 1 \mathrm{vvm}(\mathrm{B})$ and $1.5 \mathrm{vvm}(\mathrm{C})$ rpm does not have a positive effect on antagonistic agent production, because the shear forces that occur during homogenization of the cultivation medium can change the morphology of microorganism and its productivity (Nigam et al., 2012). Certainly, the results show that an increase in the aeration rate leads to an increase in the to bioreactors with agitation speed of 100 and $200 \mathrm{rpm}$ (Sousa et al., 2002). If the results obtained in bioreactors with an agitation speed of 100, 200 and $300 \mathrm{rpm}$ compare, it can be concluded that, depending on applied aeration rate, the obtained maximum inhibition zone diameter are higher in bioprocesses with an agitation speed of 100 rpm. Since the production of the antagonistic metabolite is correlated with the morphology of streptomycetes and morphology of the microorganisms (Yen, Li, 2014), it can be assumed that the lower agitation speed has a positive effect on the microorganism morphology, which results in an increase in the productivity of the antagonis
agent against $F$. avenaceum isolates (Ilic et al., 2014).

Statistical analysis showed that different combinations of agitation speed and aeration rate had significant influence $(p \leq 0.01)$ on inhibition of both $F$. avenaceum representatives. By analysing the results presented in Table 3, it can be seen that the best inhibition of $F$. avenaceum KA12 isolate was formed on an . 
Table 3. Mean values of inhibition zone diameter and significance of differences at $5 \%$ probability level

\begin{tabular}{cc|cr}
\hline \multicolumn{1}{c|}{$\begin{array}{c}\text { Conditions } \\
\text { F. avenaceum KA12 }\end{array}$} & $\begin{array}{c}\text { Mean value of } \\
\text { Conditions }\end{array}$ & $\begin{array}{c}\text { Mean value of } \\
\text { inhibition zone diameter mm }\end{array}$ \\
\hline $300 \mathrm{rpm}, 1 \mathrm{vvm}$ & $25.00 \mathrm{a}$ & $100 \mathrm{rpm}, 0.5 \mathrm{vvm}$ & $24.00 \mathrm{a}$ \\
$300 \mathrm{rpm}, 0.5 \mathrm{vvm}$ & $26.00 \mathrm{~b}$ & $300 \mathrm{rpm}, 1 \mathrm{vvm}$ & $24.33 \mathrm{a}$ \\
$100 \mathrm{rpm}, 0.5 \mathrm{vvm}$ & $27.33 \mathrm{c}$ & $300 \mathrm{rpm}, 0.5 \mathrm{vvm}$ & $24.67 \mathrm{a}$ \\
$200 \mathrm{rpm}, 0.5 \mathrm{vvm}$ & $27.67 \mathrm{c}$ & $200 \mathrm{rpm}, 0.5 \mathrm{vvm}$ & $26.00 \mathrm{~b}$ \\
$300 \mathrm{rpm}, 1.5 \mathrm{vvm}$ & $31.00 \mathrm{~d}$ & $200 \mathrm{rpm}, 1.5 \mathrm{vvm}$ & $30.00 \mathrm{c}$ \\
$200 \mathrm{rpm}, 1 \mathrm{vvm}$ & $31.67 \mathrm{~d}$ & $100 \mathrm{rpm}, 1 \mathrm{vvm}$ & $30.33 \mathrm{c}$ \\
$100 \mathrm{rpm}, 1 \mathrm{vvm}$ & $38.33 \mathrm{e}$ & $200 \mathrm{rpm}, 1.5 \mathrm{vvm}$ & $36.67 \mathrm{~d}$ \\
$200 \mathrm{rpm}, 1.5 \mathrm{vvm}$ & $38.67 \mathrm{e}$ & $100 \mathrm{rpm}, 1.5 \mathrm{vvm}$ & $37.00 \mathrm{~d}$ \\
$100 \mathrm{rpm}, 1.5 \mathrm{vvm}$ & $59.33 \mathrm{f}$ & $55.67 \mathrm{e}$ & \\
\hline
\end{tabular}

Note. Values followed by the same letter are at the same level of significance.

optimized medium at an agitation speed of $100 \mathrm{rpm}$ and aeration rate of $1.5 \mathrm{vvm}$ by $S$. hygroscopicus (lowercase letter $\mathrm{f}$ ). Also, agitation rate of $100 \mathrm{rpm}$ and aeration of $1.5 \mathrm{vvm}$ were the most suitable conditions for production of antagonistic agents effective on phytopathogenic F. avenaceum KA13 isolate (lowercase letter e). Under these conditions, formed inhibition zone diameters of F. avenaceum KA12 and KA13 isolates were 59.33 and $55.67 \mathrm{~mm}$, respectively.

In planta antagonistic activity assay. During this research phase, the effect of produced antagonistic agent on artificially inoculated apple ('Golden Delicious') fruits was investigated. Apples of approximately the same size were used for the study and after inoculation they were incubated for 10 days at $21-$ $23^{\circ} \mathrm{C}$ temperature. Before artificial inoculation with the tested phytopathogenic fungi, apples were treated with $S$. hygroscopicus supernatant obtained at $96 \mathrm{~h}$ of cultivation in the bioprocess with an agitation speed of $100 \mathrm{rpm}$ and aeration rate of $1.5 \mathrm{vvm}$. After the incubation period, the diameter of necrosis was measured and the obtained results are shown in Figure 7.

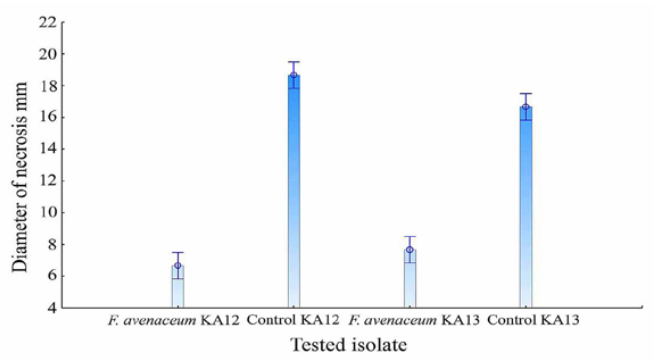

Figure 7. Mean value $( \pm \mathrm{SD})$ of necrosis diameter caused by Fusarium avenaceum KA12 and KA13 isolates on treated and control apple fruits after 10 days of incubation at $21-23^{\circ} \mathrm{C}$ temperature

Also, from the Figure 7 it can be seen that $F$. avenaceum KA12 isolate was more sensitive to produced antagonistic agent, forming a mean necrosis zone diameter of $7.67 \mathrm{~mm}$, while isolate of $F$. avenaceum KA13 isolate forming a mean necrosis zone diameter of $6.67 \mathrm{~mm}$.

The results of the experiment showed that there were statistically significant $(p<0.01)$ differences between treated and non-treated (control) fruits. This indicates that antagonistic agent produced by $S$. hygroscopicus in the bioreactor under well-defined conditions on the optimal medium composition showed very good suppression of F. avenaceum KA12 and KA13 isolates.

\section{Conclusions}

1. The results obtained from this study indicate that Streptomyces hygroscopicus has great potential in controlling the Fusarium avenaceum storage apple pathogens. The results of medium optimization, which included three most important nutrients in the medium, showed that for cultivation of S. hygroscopicus in order to produce antifungal agents, it was best to use a medium with $19.59 \mathrm{~g} \mathrm{dm}^{-3} \mathrm{C}_{3} \mathrm{H}_{8} \mathrm{O}_{3}$ (glycerol), $0.25 \mathrm{~g} \mathrm{dm}^{-3}\left(\mathrm{NH}_{4}\right)_{2} \mathrm{SO}_{4}$ (ammonium sulphate) and $1.35 \quad \mathrm{~g}^{\mathrm{dm}^{-3}} \quad \mathrm{~K}_{2} \mathrm{HPO}_{4}$ (dipotassium phosphate).

2. The results of the experiment showed that the highest antifungal activity of $S$. hygroscopicus supernatant occurred after $96 \mathrm{~h}$ of cultivation in a bioprocess with an agitation speed of $100 \mathrm{rpm}$ and aeration rate of $1.5 \mathrm{vvm}$. Under these conditions S. hygroscopicus supernatant resulted in a greater inhibition zone of 59.33 and $55.67 \mathrm{~mm}$ for $F$. avenaceum KA12 and KA13 isolates, respectively.

3 . These results were also verified in in planta studies, whereby it was found that necrosis diameters on treated apples were significantly smaller compared to non-treated control apple fruit. Also, from in vitro and in planta studies it can be concluded that the $F$. avenaceum KA12 isolate was more sensitive to antagonist agent produced by $S$. hygroscopicus, compared to $F$. avenaceum KA13 isolate.

\section{Acknowledgements}

The authors gratefully acknowledge the support of the Ministry of Education, Science and Technological development of the Republic of Serbia within the framework of project 451-03-68/2020-14/200134.

Received 18112019 Accepted 16032020

\section{References}

1. Bjelić D., Ignjatov M., Marinković J., Milošević D., Nikolić Z., Gvozdanović-Varga J., Karaman M. 2018. Bacillus isolates as potential biocontrol agents of Fusarium clove rot of garlic. Zemdirbyste-Agriculture, 105 (4): 369-376. https://doi.org/10.13080/z-a.2018.105.047

2. Chen X., Tang L., Li S., Liao L., Zhang J., Mao Z. 2011. Optimization of medium for enhancement of e-poly-Llysine production by Streptomyces sp. M-Z18 with glycerol as carbon source. Bioresouce. Technology, 102 (2): 1727-1732. https://doi.org/10.1016/j.biortech.2010.08.071

3. Cuppels D. A., Higham J., Traquair J. A. 2013. Efficacy of selected streptomycetes and a streptomycete + pseudomonad combination in the management of selected bacterial and fungal diseases of field tomatoes. Biological Control, 67 (3): 361-372.

https://doi.org/10.1016/j.biocontrol.2013.09.005

4. Dhingra O. D., Sinclair J. B. 2019. Basic plant pathology methods ( $2^{\text {nd }}$ ed.). CRC Press, $448 \mathrm{p}$.

5. Ferreira S. L. C., Bruns R. E., Ferreira H. S., Matos G. D. David J. M., Brandao G. C., da Silva E. G. P., Portugal L. A., dos Reis P. S., Souza A. S., dos Santos W. N. L. 2007. Box-Behnken design: an alternative for the optimization of analytical methods. Analitica Chimica Acta, 597 (2): 179-186. https://doi.org/10.1016/j.aca.2007.07.011

6. Gashgari R., Ameen F., Al-Homaidi E., Gherbawy Y., Al Nadhari S., Vijayan V. 2019. Mycotoxigenic fungi contaminating wheat; toxicity of different Alternaria compacta strains. Saudi Journal of Biological Science, 26: 210-215. https://doi.org/10.1016/j.sjbs.2018.10.007

7. Grahovac M., Balaž J., Grahovac J., Dodić J., Tanović B., Hrustić J., Tadijan I. 2014. Screening of antagonistic activity of selected microorganisms against apple rot pathogens. Romanian Biotechnological Letters, 19 (1): 8959-8965.

8. Hasani A., Kariminik A., Issazadeh K. 2014. Streptomycetes: characteristics and their antimicrobial activities. International Journal of Advanced Biological and Biomedical Research, 2 (1): 63-75. 
9. Hong G., Mei L., Jintao L., Huanqin D., Xianlong Z., Xiangyang L., Ying Z., Wenquan Z., Lixin Z. 2009. Medium optimization for the production of avermectin B1a by Streptomyces avermitilis $14-12 \mathrm{~A}$ using response surface methodology. Bioresource Technology, 100: 4012-4016. https://doi.org/10.1016/j.biortech.2009.03.013

10. Ilić S., Konstantinović S., Savić D., Veljković V., Joković N., Gojgić-Cvijović G. 2014. The influence of modified media with carboxymethyl cellulose on morphology and antibiotic production by Streptomyces hygroscopicus. Biotechnology and Biotechnological Equipment, 22 (1): 578-580. https://doi.org/10.1080/13102818.2008.10817516

11. Jicheng Y., Qiu L., Qiao L., Xiangdong L., Qiang S., Jianfang Y., Xiaohui Q., Shengdi F. 2008. Effect of liquid culture requirements on antifungal antibiotic production by Streptomyces rimosus MY02. Bioresource Technology, 99 . 2087-2091. https://doi.org/10.1016/j.biortech.2007.03.023

12. Juhnevica-Radenkova K., Radenkovs V., Seglina D. 2016. Influence of 1-MCP treatment and storage conditions on the development of microorganisms on the surface of apples grown in Latvia. Zemdirbyste-Agriculture, 103 (2): 215-220. https://doi.org/10.13080/z-a.2016.103.028

13. Liang J., Xu Z., Liu T., Lin J., Cen P. 2008. Effects of cultivation conditions on the production of natamycin with Streptomyces gilvosporeus LK-196. Enzyme and Microbial Technology, 42: 145-150. https://doi.org/10.1016/j.enzmictec.2007.08.012

14. Mitrović I., Grahovac A., Dodić J., Grahovac M., Dodić S., Vučurović D., Vlajkov V. 2017. Effect of agitation rate on the production of antifungal metabolites by Streptomyces hygroscopicus in a lab-scale bioreactor. Acta Periodica Technologica, 48 (48): 231-244. https://doi.org/10.2298/APT1748231M

15. Nigam V. K., Khandelwal A. K., Agarwal A., Mohan M. K., Vidyarthi A. S. 2012. Production of a thermostable nitrilase in a lab scale stirred tank bioreactor. Journal of Bioscience and Biotechnology, 4 (3): 81-89.

16. Rončević Z., Bajić B., Dodić S., Grahovac J., PajovićŚćepanović R., Dodić J. 2019. Optimization of bioethanol production from soybean molasses using different strains of Saccharomyces cerevisiae. Chemical Industry, 73 (1): 1-12. https://doi.org/10.2298/HEMIND180713004R

17. Sever Z., Ivić D., Kos T., Miličević T. 2012. Identification of Fusarium species isolated from stored apple fruit in Croatia. Archives of Industrial Hygiene and Toxicology, 63 (4): 463470. https://doi.org/10.2478/10004-1254-63-2012-2227
18. Shakeela Q., Lyua A., Zhanga J., Wua M., Chena S., Chenb W., Lia G., Yang L. 2016. Optimization of the cultural medium and conditions for production of antifungal substances by Streptomyces platensis 3-10 and evaluation of its efficacy in suppression of clubroot disease (Plasmodiophora brassicae) of oilseed rape. Biological Control, 101: 59-68. https://doi.org/10.1016/j.biocontrol.2016.06.007

19. Shimizu M., Yazawa S., Ushijama Y. 2009. A promising strain of endophytic Streptomyces sp. for biological control of cucumber anthracnose. Journal of General Plant Pathology, 75: 27-36. https://doi.org/10.1007/s10327-008-0138-9

20. Singh K. A., Chhatpar H. S. 2011. Combined use of Streptomyces sp. A6 and chemical fungicides against Fusarium wilt of Cajanus cajan may reduce the dosage of fungicides required in the field. Crop Protection, 30 (7): 770-775. https://doi.org/10.1016/j.cropro.2011.03.015

21. Sousa M. F. V. Q., Lopes C. E., Pereira N. 2002. Development of a bioprocess for the production of actinomycin-D. Brazilian Journal of Chemical Engineering, 19 (3): 277-285. https://doi.org/10.1590/S0104-66322002000300002

22. Valiuškaitè A., Uselis N., Kviklys D., Lanauskas J., Rasiukevičiūtè N. 2017. The effect of sustainable plant protection and apple tree management on fruit quality and yield. Zemdirbyste-Agriculture, 104 (4): 353-358. https://doi.org/10.13080/z-a.2017.104.045

23. Wasinpiyamongkol L., Kanchanaphum P. 2019. Isolating and identifying fungi to determine whether their biological properties have the potential to control the population density of mosquitoes. Heliyon, 5 (8): e02331. https://doi.org/10.1016/j.heliyon.2019.e02331

24. Wenneker M., Pham K. T. K., Lemmers M. E. C., de BoerF. A., van der Lans A. M., van Leeuwen P. J., Hollinger T. C., Thomma B. P. H. J. 2016. First report of Fusarium avenaceum causing wet core rot of 'Elstar' apples in the Netherlands. Plant Disease, 100 (7): 1501. https://doi.org/10.1094/PDIS-01-16-0034-PDN

25. Yen H. W., Li Y. L. 2014. The effects of viscosity and aeration rate on rapamycin production in an airlift bioreactor by using Streptomyces hygroscopicus. Journal of the Taiwan Institute of Chemical Engineers, 45: 1149-1153. https://doi.org/10.1016/j.jtice.2014.01.014

26. Yi Y. J., Li Y. S., Xi B., Li W. P., Pang L., Tong Y. D. 2015. Optimization of medium composition and culture conditions for antifungal activity of a tomato endophytic bacterium. Biological Control, 82: 69-75. https://doi.org/10.1016/j.biocontrol.2014.12.009

ISSN 1392-3196 / e-ISSN 2335-8947

Zemdirbyste-Agriculture, vol. 107, No. 3 (2020), p. 263-270

DOI $10.13080 /$ z-a.2020.107.034

\title{
Obuolių fuzarinio puvinio biologinė kontrolė naudojant Streptomyces hygroscopicus
}

\author{
J. Grahovac ${ }^{1}$, I. Mitrović ${ }^{1}$, J. Dodić ${ }^{1}$, M. Grahovac ${ }^{2}$, Z. Rončević ${ }^{1}$, S. Dodić ${ }^{1}$, A. Jokić ${ }^{1}$ \\ ${ }^{1}$ Novi Sad universiteto Technologiju fakultetas, Serbija \\ ${ }^{2}$ Novi Sad universiteto Žemès ūkio fakultetas, Serbija
}

\section{Santrauka}

Obuoliu fuzarinis puvinys, kurị sukelia grybinis patogenas Fusarium avenaceum, tapo obuoliu sandèliavimo problema Serbijoje. Siekiant atrasti galimus ekologiškus būdus, kaip kontroliuoti obuolių vaisų fuzariozę, ir atsižvelgiant i tai, kad cheminė apsauga daro neigiamą itaką žmonèms ir aplinkai, buvo atliktas tyrimas. Jo tikslas - ištirti Streptomyces hygroscopicus galimybes kontroliuoti du F. avenaceum izoliatus, gautus iš obuoliu vaisių, rodančiu puvinio simptomus. Siekiant gauti ju optimalias koncentracijas, pirmiausia buvo optimizuotos trys svarbiausios terpès maisto medžiagos: glicerolis $\left(\mathrm{C}_{3} \mathrm{H}_{8} \mathrm{O}_{3}\right)$, amonio sulfatas $\left.\left(\mathrm{NH}_{4}\right)_{2} \mathrm{SO}_{4}\right)$ ir dikalio fosfatas $\left(\mathrm{K}_{2} \mathrm{HPO}_{4}\right)$. Esant optimaliai terpès sudèčiai, laboratoriniame bioreaktoriuje buvo atlikti devyni bioprocesai, kuriu darbinis tūris buvo $2 \mathrm{dm}^{3}$. Siekiant nustatyti, kokiomis sąlygomis vyksta didžiausia antagonistinès medžiagos gamyba, taikyti skirtingi maišymo greičiai ir aeracijos normos. Terpès optimizavimo rezultatai parodė, kad optimalios glicerolio, amonio sulfato ir dikalio fosfato koncentracijos buvo atitinkamai 19,59, 0,25 ir 1,35 $\mathrm{g} \mathrm{dm}^{-3}$. Ištyrus devyniu biologinio apdorojimo variantu maišymo ir aeracijos itaka antagonistinès medžiagos gamybai nustatyta, kad bioproceso metu gautas $S$. hygroscopicus supernatanto priešgrybelinis aktyvumas, kai maišymo greitis buvo 100 aps. per min, o aeracijos norma $-1,5 \mathrm{vvm}$, yra iš esmès didesnis, palyginti su kitais bioprocesais. Esant tokioms sąlygoms, didžiausia antagonistinès medžiagos gamyba buvo pasiekta po 96 kultivavimo valandu, kai susiformavo $F$. avenaceum KA12 ir KA13 izoliatų slopinimo zonos 59,33 ir 55,67 mm skersmenys. Šis rezultatas taip pat buvo gautas ir in planta.

Reikšminiai žodžiai: bioprocesas, dirvožemio streptomicetai, ekologinè kontrolè, Fusarium avenaceum, obuolių ligos sandèliavimo metu. 